\title{
Fantse Language
}

National Cancer Institute

\section{Source}

National Cancer Institute. Fantse Language. NCI Thesaurus. Code C153917.

One of the three formal literary dialects of the Akan language. It is the major local dialect in the Central Region of Ghana, as well as in other regions from mid to southern Ghana. 